*ak RMIS View/Frint Document Cover Sheet tow

This document was retrieved from the Documentation and Records Manaqement (DRM) ISEARCH System. It is intended for Information only and may not be the most recent or updated version. Contact a Document Service Center (see Hanford Info for locations) if you need additional retrieval information.

Accession \#: D196012485

Document \#: SD-WM-ATP-158

Title/Desc:

SOFTWARE ACCEPTANCE TEST PROCEDURE FOR SURFACE MOISTURE MONITOR

Pages: 24 


\begin{tabular}{l}
\hline $\begin{array}{l}\text { 2. To: (Receiving Organizat } \\
\text { Distribution }\end{array}$ \\
\hline $\begin{array}{l}\text { 5. Proj./Prog./Dept./Div.: } \\
72520\end{array}$ \\
\hline
\end{tabular}

8. Originator Remarks:

For approval and release
3. From: (Originating organization)

Characterization Equipment Development

6. Cog. Engr.:

GF Vargo, Jr
4. Related EDT No.:

NA

7. Purchase Order No.:

NA

9. Equip./Component No.:

NA

10. System/Bldg./Facility:

NA

11. Receiver Remarks:

12. Major Assm. Dwg. No.:

NA

13. Permit/Permit Application Ko.: NA

14. Required Response Date: $1 / 19 / 96$

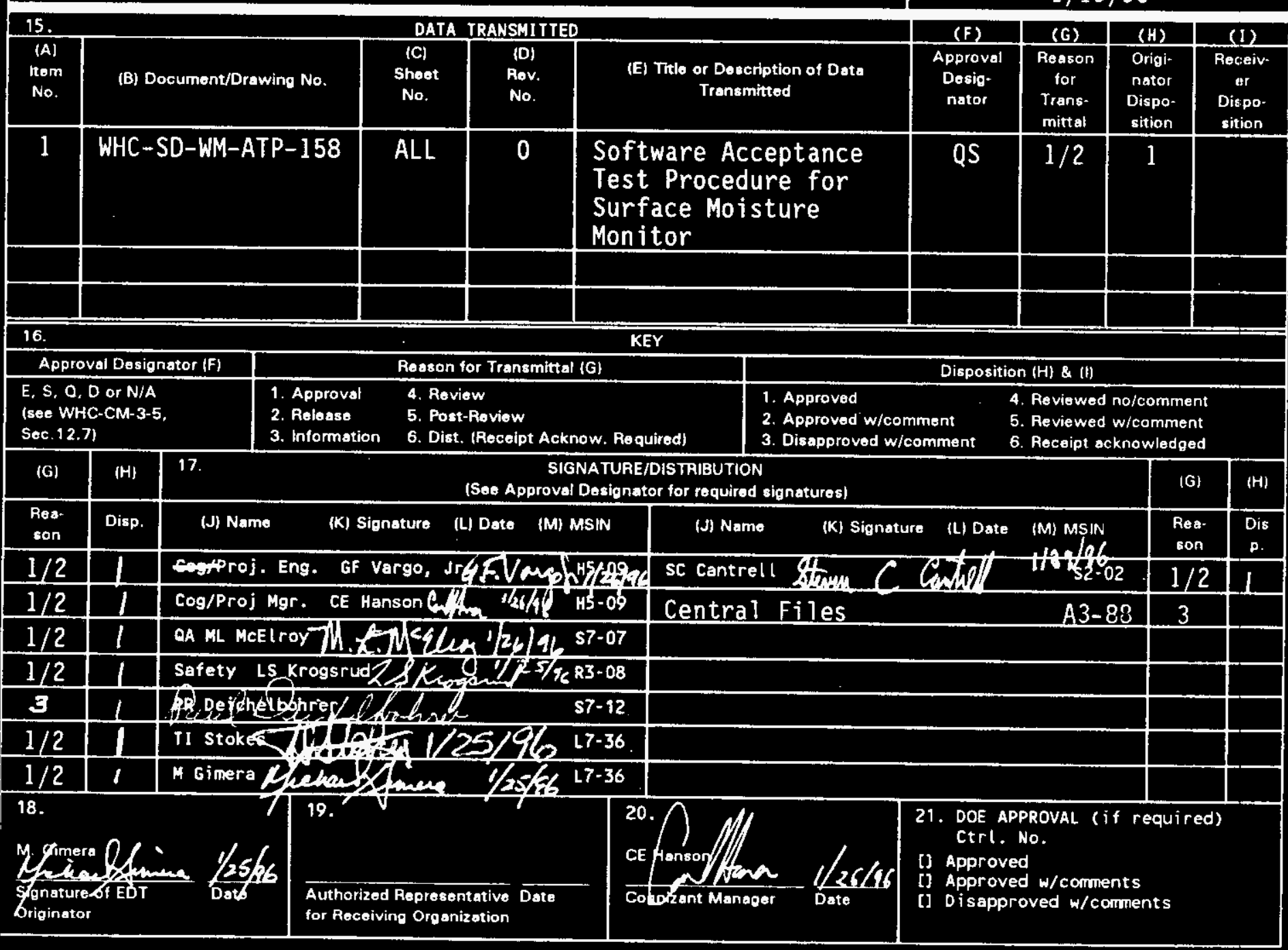

BO-7400-172-2(04/94) GEF097 


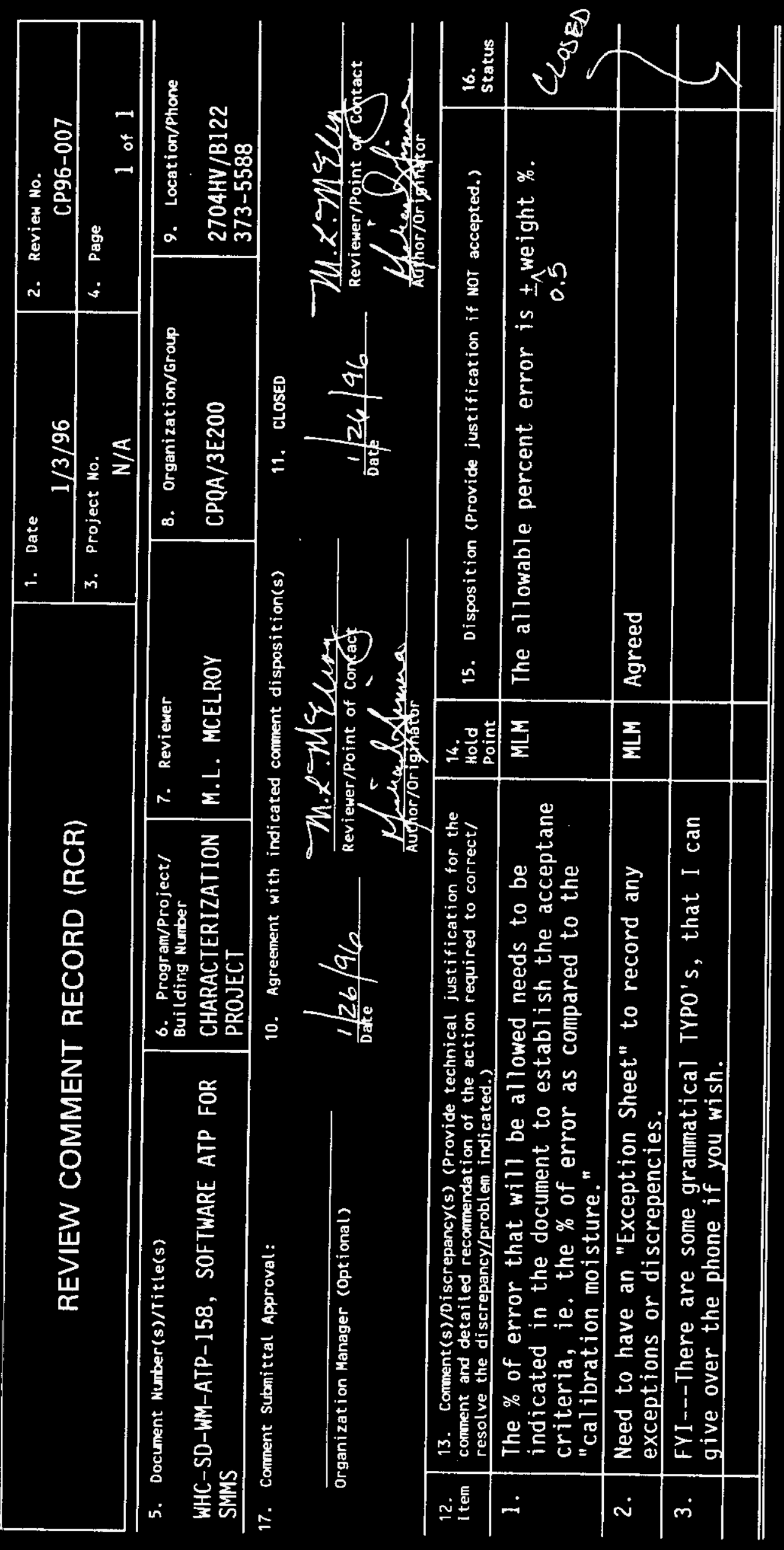

EDT-14082]

Pg. 2 of ? 


\section{SOFTWARE ACCEPTANCE TEST PROCEDURE FOR SURFACE MOISTURE MONITOR}

M. Gimera

HiLine Engineering for Westinghouse Hanford Operations, Richland, WA 99352

U.S. Department of Energy Contract DE-AC06-87RL10930

$\begin{array}{lll}\text { EDT/ECN: } & 140821 & \text { UC: } 2070 \\ \text { Org Code: } & 75250 & \text { Charge Code: N4H4F } \\ \text { B\&R Code: } & \text { EW3120074 } & \text { Total Pages: } 21\end{array}$

Key Words: Moisture, surface probe, neutron.

Abstract: Provides the software acceptance test plan and procedures for software that will perform data acquisition for the surface moisture measurement system.

TRADEMARK DISCLAIMER. Reference herein to any specific commercial product, process, or service by trade name, trademark, manufacturer, or otherwise, does not necessarily constitute or imply its endorsement, recommendation, or favoring by the United States Government or any agency thereof or its contractors or subcontractors.

Printed in the United States of America. To obtain copies of this document, contact: WHC/BCS Document Control Services, P.0. Box 1970, Mailstop H6-08, Richland WA 99352, Phone (509) 372-2420; Fax (509) 376-4989.
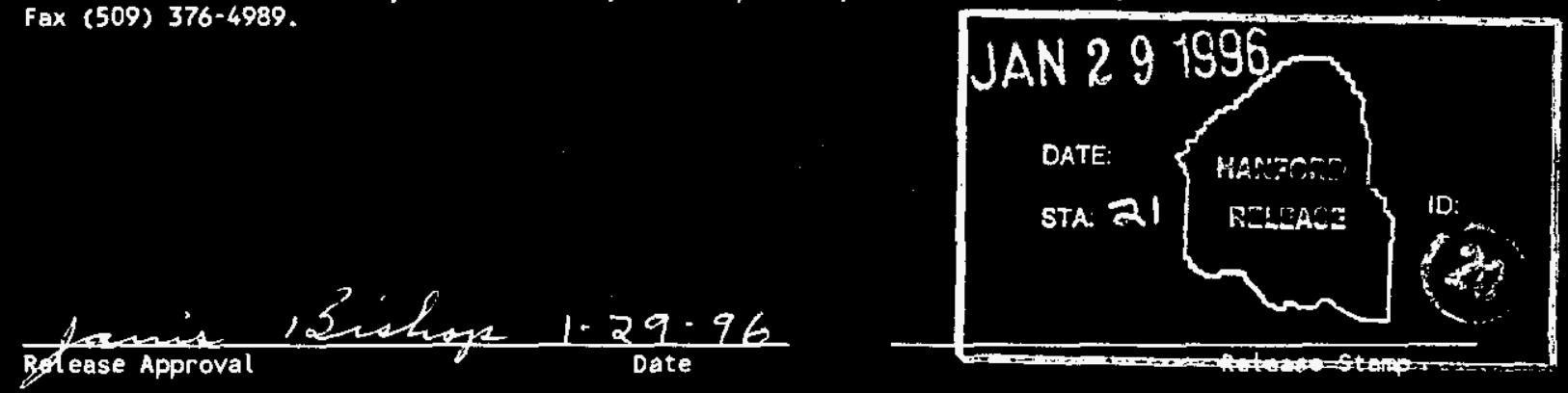

Approved for Public Release 
WHC-SD-WM-ATP-158

Rev. 0

Page 1 of 20

\section{SOFTWARE \\ ACCEPTANCE TEST PROCEDURE \\ FOR \\ SURFACE MOISTURE MONITOR}

IMPACT LEVEL QS

Issued by

Michael Gimera

January 1996

Hiline Engineering \& Fabrication Inc. 


\section{TABLE OF CONTENTS}

\section{SECTION}

PAGE

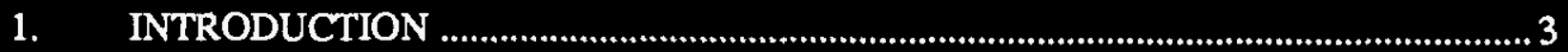

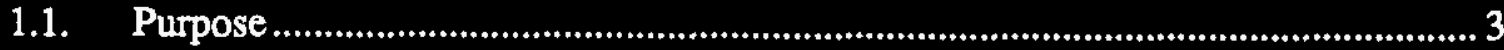

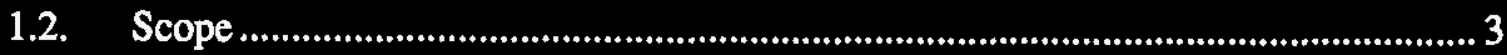

1.3. Definitions And Abbreviations ............................................................................... 3

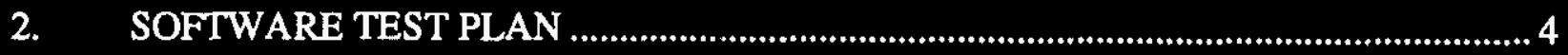

2.1. Personnel Requirements..................................................................................... 4

2.1.1. Test Engineer .............................................................................................. 4

2.1.2. Test Performer ...........................................................................................4 4

2.1.3. QA Witness ............................................................................................ 4

2.1.4. Other Witnesses ......................................................................................5

2.2. Features to be Tested.......................................................................................

2.2.1. Operator Interface Controls ........................................................................5

2.2.2. Operator Interface Indicators ...............................................................6

2.2.3. Data Recording ....................................................................................... 8

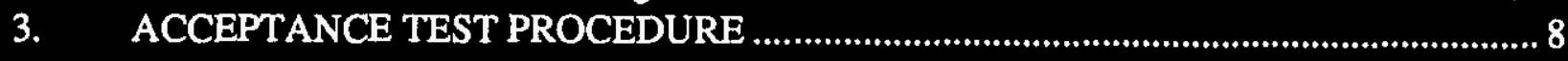

3.1. Instruction Section ..................................................................................... 8

3.1.1. System Setup .................................................................................... 8

3.1.2. Take Measurement Button and Detector Graphs ......................................... 8

3.1.3. Moisture Percentage..................................................................................... 10

3.1.4. Detector Graphs ...................................................................................... 10

3.1.5. Data File Content ........................................................................................... 10

3.1.6. Probe Position ........................................................................................ 11

3.1.7. Temperature Stabilized ......................................................................... 11

3.2. Test Execution Section ....................................................................................... 12

3.2.1. Test Data Sheets ....................................................................................... 12

3.3. Exceptions to Acceptance Test ..................................................................... 18

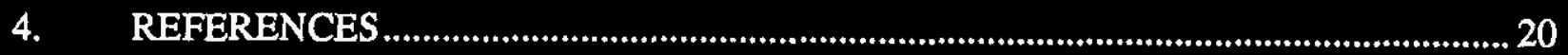




\section{SOFTWARE ACCEPTANCE TEST PROCEDURE FOR SURFACE MOISTURE MONITOR}

\section{INTRODUCTION}

\subsection{PuApose}

This document presents both a test plan and acceptance test procedures for testing the software that was developed to operate the Surface Moisture Measurement System (SMMS). Together with the forthcoming acceptance test report, this document satisfies the requirements in EP 4.1, "Design Verification Requirements." The selected method of design verification is qualification testing.

\subsection{SCOPE}

The testing described in this document covers the software that acquires data for the SMMS. In addition to the software, this testing will verify and validate the data acquisition and control hardware for the SMMS. A separate ATP will be prepared for the mechanical features not related to software.

\subsection{DEFINITIONS AND ABBREVIATIONS}

ATP Acceptance Test Procedure

EP Standard Engineering Practice (WHC-CM-6-1)

FMEF Fuels and Materials Examination Facility

MCA Multi Channel Analyzer

OM\&M Operations and Maintenance Manual (Reference 3)

SMMS Surface Moisture Measurement System

SRS Software Requirements Specification

TMAD Software developed by S. H. Finfrock. The name was derived from the phrase "tank moisture and anomaly detection". 


\section{SOFTWARE TEST PLAN}

The software acceptance test that is the subject of this document will test the features of the software described in WHC-SD-WM-SFR-010, Rev. 0, "Software Requirements Specification for Surface Moisture Monitor," herein referred to as the SRS. A comprehensive test will test every software feature described in the SRS. These features are listed in Section 2.2, "Features to be Tested". Related hardware will be indirectly tested.

\subsection{PERSONNEL REQUIREMENTS}

Each organization participating in the conduct of this test will designate personnel to assume the responsibilities and duties as defined herein for their respective roles. The names and signatures of these people shall be provided to the Test Engineer for listing on the Test Engineer's copy of the Test Data Sheet prior to the performance of any part of this test.

\subsubsection{Test Engineer}

The Test Engineer's responsibilities are as follows:

- Notify all interested parties when a change is made in the testing schedule.

A Record exceptions and test steps which are not performed.

n Notify the Test Performer of exceptions when the exception is made.

\subsubsection{Test Performer}

The Test Performer's responsibilities are as follows:

- Verify instruments are in current calibration.

1 Shall perform the test as described in this document.

- Stop any test which, in the judgment of the Test Performer, may cause damage to the system or present a unsafe condition.

- Coordinate efforts with all other assigned test performance party members.

- Observe tests and record test data (if any).

\subsubsection{QA Witness}

The QA Witness shall observe the testing and provide a signature that the test procedures were followed and results accurately recorded on the data sheets. 


\subsubsection{Other Witnesses}

No further witnesses are required during testing but interested observers will be allowed.

\subsection{FEATUAES TO BE TESTED}

This section lists each of the software features that will be tested. Inherent in testing the software is some hardware testing. The extent to which the hardware will be tested is explained in each subsection. Figure 1 shows the operator interface screen that will be helpful in understanding the descriptions and procedures that follow.

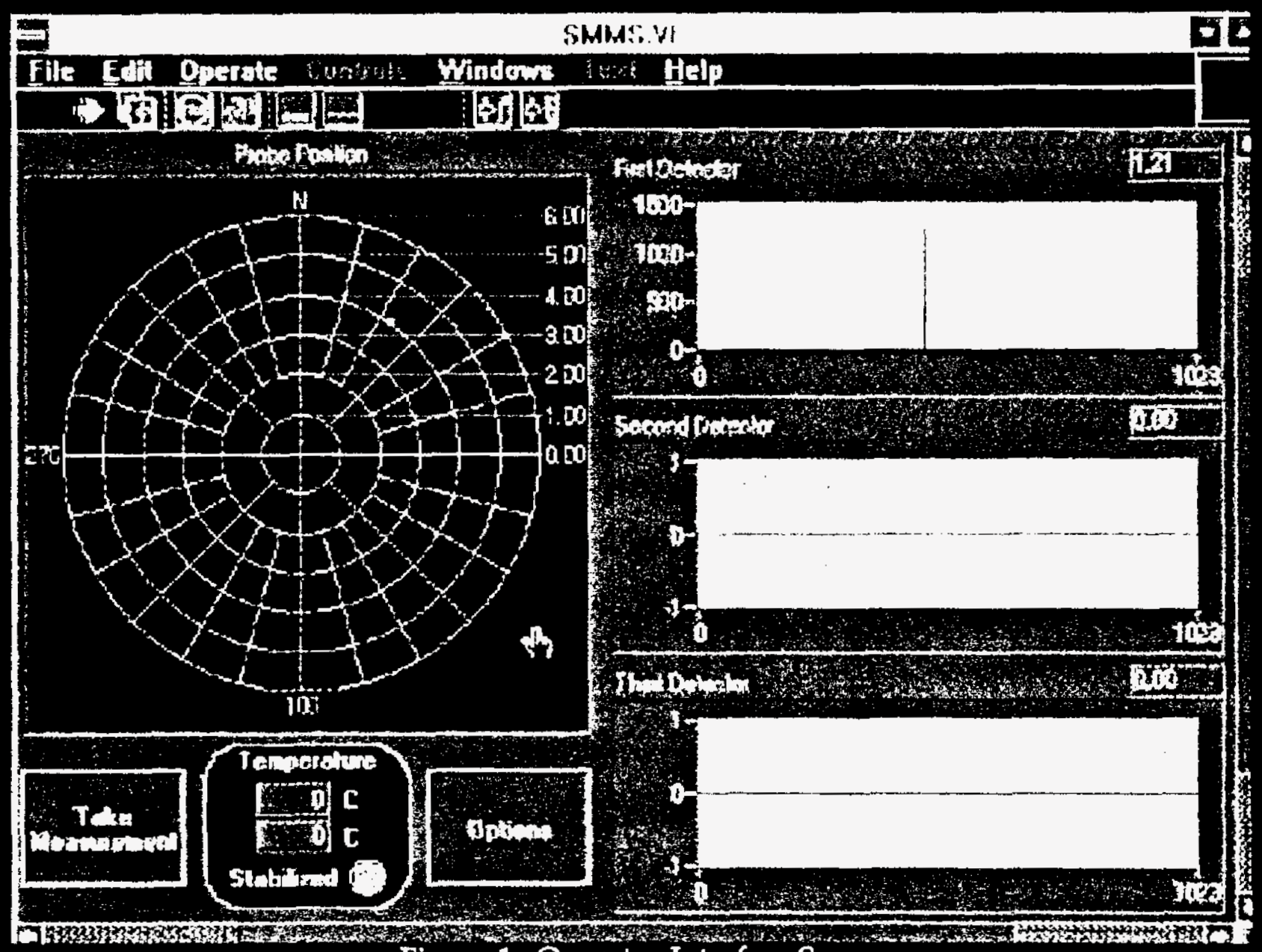

Figure 1. Operator Interface Screen

\subsubsection{Operator Interface Controls}

The SMMS instrumentation is controlled with a computer. The front panel uses only two controls, the "Take Measurement" button and the "Options" button. Each control 
can be accessed by pressing its representative icon on the computer's touch screen monitor.

When the "Take Measurement" button is "pressed" the computer will acquire data from the MCA in the NIMBN and the signal conditioners (temperature data). Testing will verify that the operation of the button results in screen updates of the detector graphs and a new data file.

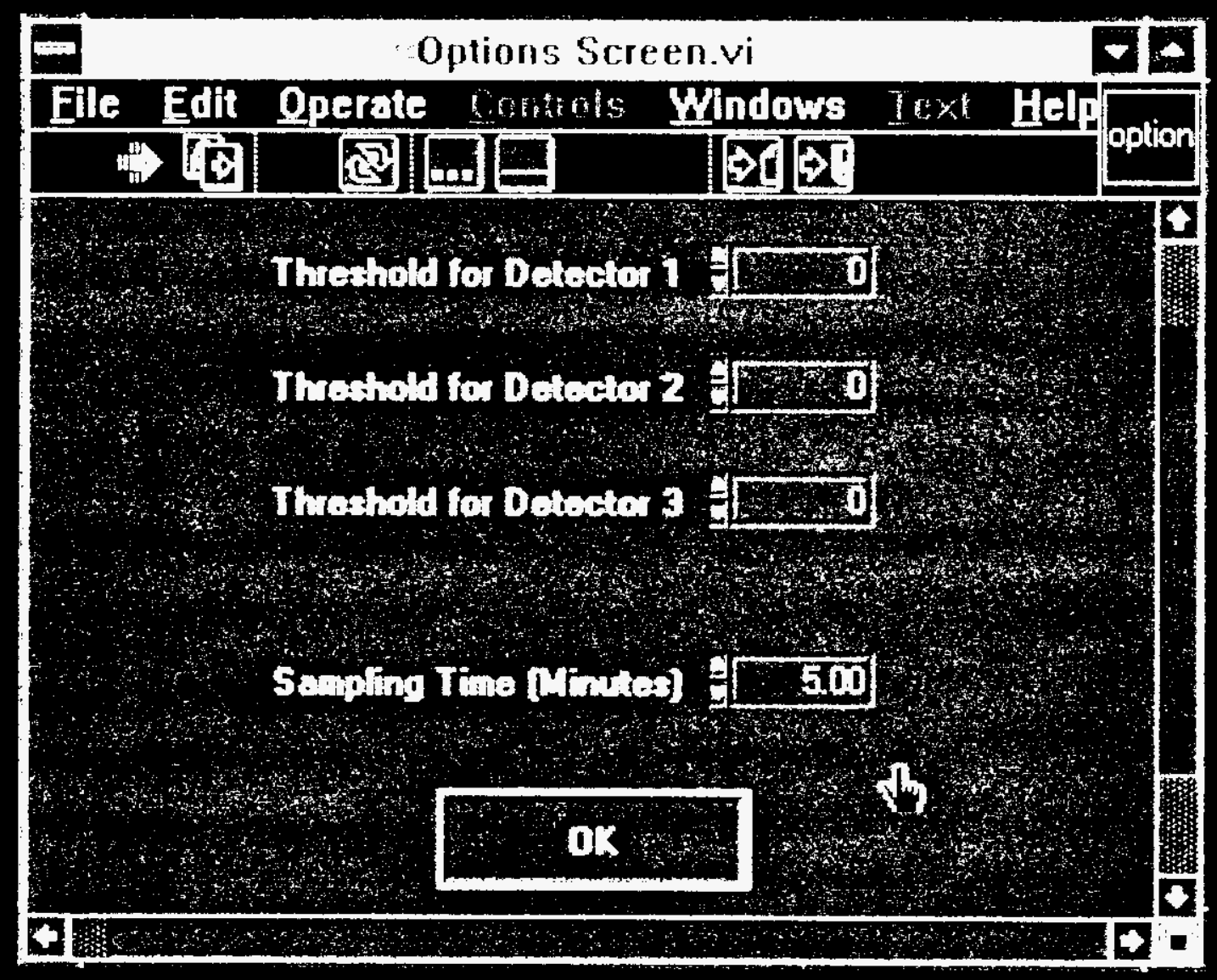

Figure 2. Options Screen

When the "Options" button is pressed, a window will be presented to the operator as shown in Figure 2. This windows allows the operator to change the threshold values for each of the three detectors and to change the sampling time when acquiring data.

\subsubsection{Operator Interface Indicatore}

The operator interface indicators consist of a graphical display of the probe position, three detector graphs (one for each detector), a temperature stabilized indicator light and the moisture percentage readouts.

When each readout is tested, the hardware associated with acquiring the data for each readout will also be tested. When comparing the information displayed and recorded 
to file with the reading from calibrated instruments, these tests will provide an overall assessment of system accuracy.

\subsubsection{Probe Position}

The probe position is displayed graphically. The display shows both the compass heading and the distance from the riser centerline on a polar plot.

The first test to be performed will verify the compass heading. This test must be performed with the deployment system suspended vertically.

A graphical display of this nature does not convey a great degree of accuracy, so the test for this indicator will only confirm approximate location of the probe. The exact location of the probe will be recorded in the data file and this is the information that will be checked for accuracy.

\subsubsection{Detector Graphs}

The detector graphs each display a response spectrum of data from the detectors in the probe. These graphs can be checked for proper response (pulse voltage height) with a pulse generator that is located in the NIMBIN. In addition, the operation of the detector graphs can be verified during operation of the probe.

\subsubsection{Temperature Stablilzed}

The temperature stabilized indicator is an icon that is displayed on the computers monitor. The icon represents a LED (Light Emitting Diode) that is red if the temperature has not stabilized and is green if the temperature has stabilized. As described in the SRS, stabilization is defined as a change of less than one degree Celsius over a period of five minutes.

In addition to the temperature stabilized light, the computer display contains a digital readout of each of the two thermisters that are located in the probe

To test the temperature stabilization feature, the probe must be placed in a temperature stable environment. The software will be started and the response timed with a stop watch to verify the five minutes. The temperature is also recorded to file and is used to adjust the count rates for comparison in TMAD code.

\subsubsection{Molsture Percentage}

The data obtained from the detectors will be used to calculate the moisture content of the surface of the waste. This calculation will be post processed with the TMAD program developed for this purpose. 
Unofficial results will be displayed on the computer screen for feedback to the operator. This result should closely approximate the official results obtained from post processing. The SMMS LabVIEW" moisture values. TMAD code was developed, documented and tested separately from the SMMS code.

This ATP will not provide a second verification and validation of TMAD code, but will check to verify that the interfaces with the TMAD code operate properly. This will be done by testing with the probe over calibration standards of known moisture content.

\subsubsection{Data Recording}

While it is important to obtain accurate data, it is also necessary to save that data in a form that can be analyzed later. The data will be stored to a computer disk file in a text format. Both the ability to record and the information recorded must be tested.

The file created by asserting the "Take Measurement" icon may be viewed with a text editor. The contents of this file will be checked to verify that the contents comply with the requirements outlined in the SRS, WHC-SD-WM-SFR-010, Rev. 0, "Software Requirements Specification for Surface Moisture Monitor."

\section{ACCEPTANCE TEST PROCEDURE}

This section provides the instructions to perform acceptance testing on the SMMS software. Although these procedures usually provide step-by-step instructions, this section on occasion makes reference to the Operator's Manual and the Installation Instructions.

\subsection{INSTRUCTION SECTION}

\subsubsection{System Setup}

Testing will be conducted in the 306E Lab, $305 \mathrm{Lab}$ and/or FMEF. The hardware should be setup in accordance with the instructions in Section 5.1, "DAV Startup Sequence" of the OM\&M (Reference 3). A 110 VAC power source (15 Amp) will be connected to the data acquisition van. Software start-up is also covered in the OM\&M.

\subsubsection{Take Measurement Button and Detector Graphs}

Test successful initialization.

\footnotetext{
${ }^{1} \mathrm{LabView}^{\mathrm{TM}}{ }^{1}$ is a registered trademark of National Instruments, Austin, Texas.
} 
3.1.2.1 Turn on power to instrumentation per Section 5.1 of the OM\&M. Computer screen should show Windows ${ }^{\mathrm{TM} 1}$ interface.

3.1.2.2 Start LabVIEW ${ }^{T M}$ program by double clicking on LabVIEW TM icon.

3.1.2.3 Close current LabVIEW ${ }^{\mathrm{TM}}$ window by selecting "Close" from the File menu. If unfamiliar with basic Windows commands refer to the manual that came with the Windows operating system.

3.1.2.4 Select "Open VI" from resulting dialog box.

3.1.2.5 Select "SMMS.vi" from the file selector dialog box.

3.1.2.6 The SMMS front panel should now be displayed on the computer screen (see Figure 1). Note the result on the test data sheet.

3.1.2.7 Press the "Options" button icon. A data entry screen should be displayed as shown in Figure 2. Verify that the sampling time is set to five minutes.

3.1.2.8 Click on the LabVIEW"M "run" icon.

3.1.2.9 Install source in probe per instructions in the OM\&M.

3.1.2.10 Position the probe on a calibration standard. The calibration standard is an aluminum drum filled with sand and aluminum hydrate. It is sealed with a lid. The probe should be placed on the lid near the center of the drum.

3.1.2.11 Press the "Take Measurement" icon.

3.1.2.12 Record whether the detector graphs update (page 13). Updating of graphs can be detected by the change of numbering along the horizontal axis. Also the results of the moisture percentage calculation is displayed on a pop-up window when the graphs have finished updating.

3.1.2.13 Record the resulting moisture percentages (page 13). Also record the maximum pulse value for each of the detector graphs.

3.1.2.14 Press the "Options" button icon. A data entry screen should be displayed as shown in Figure 2.

3.1.2.15 Change the sampling time from the default five minutes to 2.5 minutes.

3.1.2.16 Press in the "OK" button icon to dismiss the Options window.

3.1.2.17 Press in the "Take Measurement" icon to begin recording data.

\footnotetext{
${ }^{1}$ Windows $^{\mathrm{TM}}{ }^{1}$ is a registered trademark of Microsoft Corporation, Redmond, Washington.
} 
3.1.2.18 Record the maximum pulse value for each of the detector graphs. The values should be one half the values recorded in Step 3.1.2.13.

\subsubsection{Molsture Percentage}

A moisture percentage has already been taken in Section 3.1.2.

3.1.3.1 Record the value obtained in Step 3.1.2.13 of Section 3.1.2 (page 13).

3.1.3.2 Each calibration standard represents a particular moisture percentage. Record the moisture percentage of the calibration standard used in Section 3.1.2. This value should be within one weight percent of the value from step 3.1.3.1.

\subsubsection{Detector Graphs}

3.1.4.1 Connect the pulse generator to the Multichannel Analyzer (MCA). The pulse generator is located in the NIMBIN inside the data acquisition van. Using a $50 \Omega$ cable with BNC connectors, attach one end to the pulse out port of the pulse generator and connect the other end to the Port 1 input of the MCA.

3.1.4.2 If the SMMS software is not running, start the software per instructions in the OM\&M.

3.1.4.3 Press the "Take Measurement" control on the front panel.

3.1.4.4 A peak should be displayed on the Detector One graph. Record this result to the data sheets.

3.1.4.5 Repeat steps 3.1.4.1 through 3.1.4.4 for detectors two and three. For detector two, the pulse generator is connected the Port 2 of the MCA. For detector three, the pulse generator is connected the Port 3 of the MCA.

\subsubsection{Data Flle Content}

3.1.5.1 Use a text editor to view the file "C: \DATA \SMMS $\backslash m m-d d-y y \backslash m m-d d-$ yy.001".

3.1.5.2 Verify the header information in the file matches the following:

File: mm-dd-yy.001

[Date and time stamp]

Program: Surface.vi v1.0

Probe Position: Compass heading $X X X^{\circ}$ Radial Distance: $X X X \mathrm{ft}$. Depth: $X X X$ in. Sampling Time: $X X X$ Minutes

3.1.5.3 Record the results from Step 3.1.5.2 to the test data sheet. 
3.1.5.4 Using the text editor, verify that three arrays of data exist (one spectrum for each detector). An array of data consists of 1,024 integers. Verify that two probe temperatures exist. Verify that the results of the moisture probe calculation are written to file.

3.1.5.5 Record the results from Step 3.1.5.4 to the test data sheet.

\subsubsection{Probe Position}

3.1.6.1 Suspend the deployment system in the vertical position.

3.1.6.2 The probe position is displayed on the screen of the computer. Record the position of the probe in degrees and feet from the computer screen.

3.1.6.3 Assert the "Take Measurement" icon.

3.1.6.4 Use a text editor to read the resulting data file. The file is located in the directory, "C: \DATA \SMMS \mm-dd-yy.

3.1.6.5 Record the position of the probe from reading the data file to the test data sheet.

3.1.6.6 Using a compass measure the compass heading of the deployment arm and record to the test data sheet.

3.1.6.7 Using a linear scale and plumb bob record the distance of the probe from centerline or riser. The centerline of the riser is the centerline of the deployment system mast. Record result to test data sheet.

3.1.6.8 Using a linear scale record the distance that the probe is below the deployment system arm.

\subsubsection{Temperature Stabllized}

This test should be performed in the 305 lab environmental chamber .

3.1.7.1 Place probe in environmental chamber.

3.1.7.2 Wait for temperature to stabilize in chamber.

3.1.7.3 Start SMMS software in accordance with Section 5.1 of the OM\&M.

3.1.7.4 Record the length of time for the "Temperature Stabilized" icon to turn from red to green. The time should be five minutes.

3.1.7.5 Record the temperatures displayed on the computer screen. 
3.1.7.6 Record the temperature of the environmental chamber. This temperature should not vary more than $3^{\circ} \mathrm{C}$ from the temperature displayed on the computer screen.

3.1.7.7 Change temperature in environmental chamber.

3.1.7.8 Record whether the color of the "Temperature Stabilized" icon returned to red.

3.1.7.9 Repeat steps 3.1.7.5 through 3.1.7.8 for two additional temperatures.

\subsection{TEST EXECUTION SECTION}

\subsubsection{Test Data Sheets}

The test data sheets are shown on the following pages.

Please print name of test personnel below:

Test Engineer

Test Performer

QA/QC Representative 
Test 3.1.2 Take Measurement Button and Detector Graphs

Step 3.1.2.6

Is SMMS front panel displayed on the screen?

Test Engineer

$\mathbf{Y} \quad \mathbf{N}$

QA/QC Rep

Date

Date

\section{Step 3.1.2.7}

Is the sampling time set to five minutes?

Test Engineer

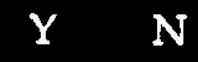

QA/QC Rep

Date

Date

\section{Step 3.1.2.12}

Do detector graphs update on the screen?

Test Engineer

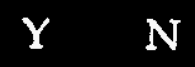

QA/QC Rep

Date

Date

\section{Step 3.1.2.13}

Moisture Percentage 1: $\quad$ Percentage

Pulse height

Moisture Percentage 2: $\quad$ Percentage

Pulse height

Moisture Percentage 3: Percentage

Pulse height

Test Engineer

Date

QA/QC Rep

Date

\section{Step 3.1.2.18}

Moisture Percentage 1: Percentage

Pulse height

Moisture Percentage 2: $\quad$ Percentage

Pulse height

Moisture Percentage 3: Percentage

Pulse height

Test Engineer

Date

QA/QC Rep

Date

\section{Test 3.1.3 Moisture Percentage}




\section{Step 3.1.3.1}

Moisture Percentage 1: $\quad$ Percentage

Moisture Percentage 2: $\quad$ Percentage

Moisture Percentage 3: $\quad$ Percentage

Test Engineer

QA/QC Rep

Step 3.1.3.2

Calibration Moisture:

Percentage

Test Engineer

QA/QC Rep

Test 3.1.4 Detector Graphs

Step 3.1.4.4

Detector 1:

Channel

Test Engineer

QA/QC Rep

Step 3.1.4.5

Detector 2:

Detector 3:

Channel

Channel

Test Engineer

QA/QC Rep

\section{Test 3.1.5 Data File Content}

\section{Step 3.1.5.3}

Does data file contain the header information expected in Step 2)? $\mathbf{Y} \mathbf{N}$ Test Engineer Date QA/QC Rep Date

\section{Step 3.1.5.5}


WHC-SD-WM-ATP-158

Rev. 0

Page 15 of 20

Does data file contain the data information expected in Step 4)?

$\mathbf{Y} \quad \mathbf{N}$

Test Engineer

Date

QA/QC Rep

Date

\section{Test 3.1.6 Probe Position}

\section{Step 3.1.6.2}

Probe position as determined from computer screen:

Compass Heading degrees

Radial Distance feet

Vertical Distance inches

Test Engineer

Date

QA/QC Rep

Date

\section{Step 3.1.6.5}

Probe position as determined from data file:

Compass Heading degrees

Radial Distance feet

Vertical Distance inches

Test Engineer

Date

QA/QC Rep

Date

\section{Step 3.1.6.6}

Probe position as determined from manual measurements:

Compass Heading degrees

Test Engineer

Date

QA/QC Rep

Date

Step 3.1.6.7

Radial Distance feet

Test Engineer

Date 
QA/QC Rep

Date

\section{Step 3.1.6.8}

Vertical Distance inches

Test Engineer

Date

QA/QC Rep

Date

Test 3.1.7 Temperature Stabilized

Step 3.1.7.4

Time for LED icon to turn from red to green (expected 5 minutes)

Test Engineer

Date

QA/QC Rep

Date

\section{Step 3.1.7.5}

Temperatures displayed on screen:

${ }^{\circ} \mathrm{C}$ ${ }^{\circ} \mathrm{C}$

Test Engineer

Date

QA/QC Rep

Date

\section{Step 3.1.7.6}

Temperature of environmental chamber:

${ }^{\circ} \mathrm{C}$

Test Engineer

Date

QA/QC Rep

Date

\section{Step 3.1.7.8}

Does LED icon turn from green to red when temperature changes?

$\mathbf{Y} \mathbf{N}$ Test Engineer

Date

QA/QC Rep

Date

\section{Step 3.1.7.9}

Temperatures displayed on screen:

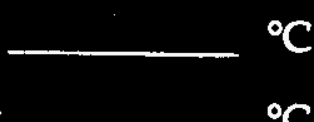

${ }^{\circ} \mathrm{C}$

Temperature of environmental chamber: ${ }^{\circ} \mathrm{C}$

Does LED icon turn from green to red when temperature changes? 
WHC-SD-WM-ATP-158

Rev. 0

Page 17 of 20

Temperatures displayed on screen: $\quad \ldots$

${ }^{\circ} \mathrm{C}$

Temperature of environmental chamber:

${ }^{\circ} \mathrm{C}$

Does LED icon turn from green to red when temperature changes?

$\mathbf{N} \mathbf{N}$

Test Engineer

Date

QA/QC Rep

Date 
WHC-SD-WM-ATP-158

Rev. 0

Page 18 of 20

\subsection{EXCEPTIONS TO ACCEPTANCE TEST}

The test exception sheet is shown on the following page. 
WHC-SD-WM-ATP-158

Rev. 0

Page 19 of 20

EXCEPTIONS TO SOFTWARE ACCEPTANCE TEST

FOR

SMMS SOFTWARE

\begin{tabular}{|c|c|c|c|c|c|}
\hline \multicolumn{3}{|c|}{ EXCEPTIONS } & \multicolumn{3}{|c|}{ CORRECTION APPROVAL } \\
\hline Paragraph No. & Date & Description & Org. & Initials & Date \\
\hline & & & & & \\
\hline & & & & & \\
\hline & & & & & \\
\hline & & & & & \\
\hline & & & & & \\
\hline & & & & & \\
\hline & & & & & \\
\hline & & & & & \\
\hline & & & & & \\
\hline & & & & & \\
\hline & & & & & \\
\hline & & & & & \\
\hline
\end{tabular}

TEST APPROVED WITH EXCEPTIONS

Test Engineer

Date

Quality Assurance

Date 
WHC-SD-WM-ATP-158

Rev. 0

Page 20 of 20

\section{REFERENCES}

1. WHC-CM-6-1, "Standard Engineering Practices".

2. ANSI/IEEE Standard 829-1983, "TEEE Standard for Software Test Documentation".

3. Ritter, G. A., 1995, Surface Moisture Measurement System Operation and Maintenance Manual, WHC-SD-WM-OMM-024, Rev. 0, Westinghouse Hanford Company, Richland, Washington. 